\title{
Contribution of Matrix Metalloproteinase-1 Genotypes to Colorectal Cancer in Taiwan
}

\author{
MING-HSIEN WU ${ }^{1,2,3 *}$, TE-CHENG YUEH ${ }^{1,2,3 *}$, WEN-SHIN CHANG ${ }^{4 *}$, CHIA-WEN TSAI ${ }^{1,4}$, \\ CHUN-KAI FU ${ }^{1,3}$, MEI-DUE YANG ${ }^{4}$, CHIEN-CHIH YU ${ }^{5}$ and DA-TIAN BAU ${ }^{1,4,6}$ \\ ${ }^{I}$ Graduate Institute of Biomedical Sciences, China Medical University, Taichung, Taiwan, R.O.C.; \\ ${ }^{2}$ Division of Colon and Rectal Surgery, Taichung Armed Forces General Hospital, Taichung, Taiwan, R.O.C.; \\ ${ }^{3}$ National Defense Medical Center, Taipei, Taiwan, R.O.C.; \\ ${ }^{4}$ Terry Fox Cancer Research Laboratory, Department of Medical Research, \\ China Medical University Hospital, Taichung, Taiwan, R.O.C.; \\ ${ }^{5}$ School of Pharmacy, China Medical University, Taichung, Taiwan, R.O.C.; \\ ${ }^{6}$ Department of Bioinformatics and Medical Engineering, Asia University, Taichung, Taiwan, R.O.C.
}

\begin{abstract}
Background/Aim: Matrix metalloproteinase-1 is responsible for extracellular matrix regulation, and its genetic role in colorectal cancer $(C R C)$ is unclear. The aim of the study was to investigate the contribution of Matrix metalloproteinase-1 genotypes to CRC risk in Taiwan. Materials and Methods: A total of 362 cases and 362 controls were included and their MMP-1 -1607 (rs1799705) genotypes were examined. The environmental factors and clinical-pathological records were also analyzed. Results: The genotypic frequency of MMP-1 rs 1799750 were different between the CRC and control groups ( $p$ for trend=0.0083). $1 G / 2 G$ and $1 G / 1 G$ were associated with lower risk ( $p=0.0438$ and 0.0030, adjusted OR=0.73 and 0.54, 95\%CI =0.54-0.90 and 0.37-0.83). Among non-smokers, those with $1 G / 2 G$ and $1 G / 1 G$ genotypes were at 0.70 - and 0.48-fold odds of having CRC. Among non-alcohol drinkers, people with $1 G / 2 G$ and $1 G / 1 G$ genotypes were at 0.71 - and 0.54-fold odds. The 1G/1G genotypes were statistically lower among CRC patients with lymph node metastasis (7.2\%) than those without (19.0\%). Conclusion: The genotypes at MMP-1 rs 1799705 play a role in determining susceptibility to $C R C$ risk in Taiwan.
\end{abstract}

This article is freely accessible online.

*These Authors contributed equally to the study.

Correspondence to: Da-Tian Bau, Terry Fox Cancer Research Laboratory, China Medical University Hospital, 2 Yuh-Der Road, Taichung, 404 Taiwan, R.O.C. Tel: +886 422053366 Ext. 5805, e-mail: datian@mail.cmuh.org.tw; artbau2@gmail.com

Key Words: Colorectal cancer, genotype, $M M P-1$, polymorphism, Taiwan.
Colorectal cancer (CRC), the second most common occurring cancer in females and the third most common cancer in males, it has over 1.8 million new cases in 2018 all over the world (1-3). The incidence and mortality rates of CRC vary by a factor of as high as ten (2-4). From the viewpoint of epidemiology, the environmental factors such as meat consumption, cigarette smoking, and exposure to carcinogens contribute to about $85 \%$ of CRC etiology $(5,6)$. At the same time, at least $15-20 \%$ of CRC etiology could be traced with familial cancer history $(7,8)$. In Taiwan, the incidence rate of CRC is on top of all types of cancer, while the mortality rate of CRC has been listed as the third among all types of cancer. With the efforts of some scientists, specific biomarkers for CRC have been reported within the decade (913). However, the interactions between genomic and environmental risk factors still need further investigation.

Matrix metalloproteinases (MMPs), is a family of proteins that degrade extracellular matrix proteins including collagen, laminin, and fibronectin, and so on (14). They also play a critical role in cell proliferation, differentiation, apoptosis, invasion, migration and immune responses $(15,16)$. In recent years, it has been shown that genotypic variants of $M M P S$ were associated with the susceptibility of several types of cancer (17-20). Among these MMPs, MMP-1 is the first vertebrate collagenase to be purified and cloned, and is encoded by the $M M P 1$ gene $(21,22)$. The most commonly studied MMP-1 polymorphism is rs1799750, which is located at -1607 of the promoter region. The variants may consist the " $2 \mathrm{G}$ " insertion polymorphism, which has been reported to lead to higher levels of MMP-1 in the serum, potentially to higher levels of collagen breakdown than the $1 \mathrm{G}$ genotype (23). In a meta-analysis, it was concluded that people who have MMP-1 rs1799750 2G/2G genotypes may have a slightly higher metastasis rate (24). As far as CRC is 
Table I. Summary of selected data from 362 patients with colorectal cancer and 362 matched non-cancer healthy controls.

\begin{tabular}{|c|c|c|c|c|c|}
\hline \multirow[t]{2}{*}{ Characteristic } & \multicolumn{2}{|c|}{ Controls $(n=362)$} & \multicolumn{2}{|c|}{ Cases $(n=362)$} & \multirow[t]{2}{*}{$p$-Value } \\
\hline & $\mathrm{n}$ & $\%$ & $\mathrm{n}$ & $\%$ & \\
\hline \multicolumn{6}{|l|}{ Age (years) } \\
\hline$\leq 60$ & 95 & $26.2 \%$ & 95 & $26.2 \%$ & 1.0000 \\
\hline$>60$ & 267 & $73.8 \%$ & 267 & $73.8 \%$ & \\
\hline \multicolumn{6}{|l|}{ Gender } \\
\hline Male & 203 & $56.1 \%$ & 203 & $56.1 \%$ & 1.0000 \\
\hline Female & 159 & $43.6 \%$ & 159 & $43.9 \%$ & \\
\hline \multicolumn{6}{|l|}{ Smoking habits } \\
\hline Yes & 84 & $23.2 \%$ & 91 & $25.1 \%$ & 0.5434 \\
\hline No & 278 & $76.8 \%$ & 271 & $74.9 \%$ & \\
\hline \multicolumn{6}{|c|}{ Alcohol drinking habits } \\
\hline Yes & 51 & $14.1 \%$ & 44 & $12.2 \%$ & 0.4410 \\
\hline No & 311 & $85.9 \%$ & 318 & $87.8 \%$ & \\
\hline \multicolumn{6}{|l|}{ BMI } \\
\hline$<24$ & 175 & $48.3 \%$ & 193 & $53.3 \%$ & 0.1809 \\
\hline$\geq 24$ & 187 & $51.7 \%$ & 169 & $46.7 \%$ & \\
\hline \multicolumn{6}{|c|}{ Tumor size $(\mathrm{cm})$} \\
\hline$<5$ & & & 195 & $53.9 \%$ & \\
\hline$\geq 5$ & & & 167 & $46.1 \%$ & \\
\hline \multicolumn{6}{|l|}{ Location } \\
\hline Colon & & & 257 & $71.0 \%$ & \\
\hline Rectum & & & 105 & $29.0 \%$ & \\
\hline \multicolumn{6}{|c|}{ Lymph node involvement } \\
\hline Negative & & & 210 & $58.0 \%$ & \\
\hline Positive & & & 152 & $42.0 \%$ & \\
\hline
\end{tabular}

SD, Standard deviation; BMI, body mass index. aBased on Chi-square test without Yates' correction.

concerned, MMP-1 has been reported to be overexpressed and closely related to poor prognosis (25-27). Based on above clues, we hypothesize that the variant genotypes at the promoter region at $M M P-1$ rs1799750 may play a role in determining the susceptibility for CRC in Taiwan.

\section{Materials and Methods}

Collection of 362 CRC cases and 362 controls. The investigated population has been recruited as described in our previous studies (9-12). Concisely, CRC cases have been recruited at the outpatient clinics of general surgery by well-trained colleagues. The pathological-clinical data of each participant were defined, graded and recorded by experienced doctors. We reselected some of the controls to match well the control and case group by age and gender. All the procedures were approved and supervised by the Institutional Review Board of the China Medical University Hospital (IRB project identification coding number: DMR99-IRB108).

MMP-1 rs1799750 genotyping methodology. The genomic DNA from peripheral blood leukocytes of all participants were extracted and stored at $-80^{\circ} \mathrm{C}$ as previously published $(9,10)$. The $M M P-1$ rs1799750 genotyping methodology is the same as previously reported $(17,19)$. The polymerase chain reaction (PCR) conditions set for $M M P-1$ rs 1799750 genotyping were one cycle at $94^{\circ} \mathrm{C}$ for
$5 \mathrm{~min} ; 35$ cycles at $94^{\circ} \mathrm{C}$ for $30 \mathrm{sec}$, one cycle at $57^{\circ} \mathrm{C}$ for $30 \mathrm{sec}$ and one cycle at $72^{\circ} \mathrm{C}$ for $30 \mathrm{sec}$ and a final extension at $72^{\circ} \mathrm{C}$ for $10 \mathrm{~min}$.

Statistical analysis. Pearson's Chi-square test without Yates' correction was applied to compare the distribution of $M M P-1$ genotypic and allelic distributions between CRC and control groups. The associations between the $M M P-1$ genotypes and CRC risk were estimated by odds ratios (ORs) as well as their $95 \%$ confidence intervals (CIs) from logistic regression analysis.

\section{Results}

Basic indexes between CRC patient and control groups. The distribution of age and gender for the 362 CRC patients and 362 non-cancer healthy controls is shown and compared in Table I. There were $203(56.1 \%)$ males and 159 (43.6\%) females in the CRC group, and we matched the age and gender very well, so there was no significant difference between the two groups as for the frequencies of age or gender (both $p>0.05$ ) (Table I). As for the personal habits, $91(25.1 \%)$ of the CRC group had smoking habits, while 44 (12.2\%) had alcohol drinking habits. They were not significantly different from those of the control group (23.2\% had smoking and $14.1 \%$ had alcohol drinking habit, 
Table II. Distribution of matrix metalloproteinase-1 rs1799750 genotypic frequencies among the colorectal cancer patients and healthy controls.

\begin{tabular}{|c|c|c|c|c|}
\hline & Cases, n (\%) & Controls, $\mathrm{n}(\%)$ & Adjusted OR $(95 \% \mathrm{CI})^{\mathrm{a}}$ & $p$-Value ${ }^{\mathrm{b}}$ \\
\hline \multicolumn{5}{|l|}{ rs1799750 } \\
\hline $2 \mathrm{G} / 2 \mathrm{G}$ & $160(44.2)$ & $124(34.3)$ & 1.00 (Reference) & \\
\hline $1 \mathrm{G} / 2 \mathrm{G}$ & $151(41.7)$ & $163(45.0)$ & $0.73(0.54-0.90)$ & 0.0438* \\
\hline $1 \mathrm{G} / 1 \mathrm{G}$ & $51(14.1)$ & $75(20.7)$ & $0.54(0.37-0.83)$ & $0.0030 *$ \\
\hline$p_{\text {trend }}$ & & & & $0.0083 *$ \\
\hline \multicolumn{5}{|l|}{ Carrier comparison } \\
\hline $2 \mathrm{G} / 2 \mathrm{G}+1 \mathrm{G} / 2 \mathrm{G}$ & $311(85.9)$ & $287(79.3)$ & 1.00 (Reference) & \\
\hline $1 \mathrm{G} / 1 \mathrm{G}$ & $51(14.1)$ & $75(20.7)$ & $0.65(0.48-0.94)$ & 0.0186* \\
\hline $2 \mathrm{G} / 2 \mathrm{G}$ & $160(44.2)$ & $124(34.3)$ & 1.00 (Reference) & \\
\hline $1 \mathrm{G} / 1 \mathrm{G}+1 \mathrm{G} / 2 \mathrm{G}$ & $202(55.8)$ & $238(65.7)$ & $0.62(0.42-0.81)$ & $0.0061 *$ \\
\hline
\end{tabular}

OR: Odds ratio; CI: confidence interval; $p_{\text {trend }}$ : $p$ for trend. aData have been adjusted for confounding factors age, gender, smoking, alcohol consumption and BMI status. bBased on Chi-square test without Yates' correction. *Bold values indicate statistical significance.

Table III. Allelic frequencies for matrix metalloproteinase-1 rs 1799750 polymorphisms among colorectal cancer patients and healthy controls.

\begin{tabular}{lcccc}
\hline Allelic type & Cases, $\mathrm{n}(\%) \mathrm{n}=724$ & Controls, $\mathrm{n}(\%) \mathrm{n}=724$ & ${\text { Adjusted OR }(95 \% \mathrm{CI})^{\mathrm{a}}} p_{\text {-Value }}^{\mathrm{b}}$ \\
\hline rs1799750 & & & & \\
Allele 2G & $471(65.1)$ & $411(56.8)$ & 1.00 (Reference) & $\mathbf{0 . 7 3 ( \mathbf { 0 . 5 2 } - \mathbf { 0 . 8 1 } )}$ \\
Allele 1G & $253(34.9)$ & $313(43.2)$ & $\mathbf{0 . 0 0 1 2} *$ \\
\hline
\end{tabular}

OR: Odds ratio; CI: confidence interval. aData have been adjusted for confounding factors age, gender, smoking, alcohol consumption and BMI status. bBased on Chi-square test without Yates' correction. *Bold values indicate statistical significance.

respectively) (Table I). The control group had $51.7 \%$ people with $\mathrm{BMI} \geq 24$, while case group had $46.7 \% \quad(p=0.1809)$ (Table I).

Association analysis of MMP-1 rs1799750 genotypes with $C R C$ risk. The genotyping pattern of MMP-1 rs 1799750 among the CRC and control groups are shown in Table II. First, the genotypic frequency distribution pattern of $M M P$ 1 rs1799750 were different between the CRC and control groups ( $p$ for trend $=0.0083$ ) (Table II). In detail, the $M M P$ 1 rs1799750 heterozygous $1 \mathrm{G} / 2 \mathrm{G}$ and homozygous $1 \mathrm{G} / 1 \mathrm{G}$ variant genotypes were associated with lower risk for colorectal cancer than the wild-type $2 \mathrm{G} / 2 \mathrm{G}$ genotype ( $p=0.0438$ and 0.0030 , adjusted $\mathrm{OR}=0.73$ and 0.54 , $95 \% \mathrm{CI}=0.54-0.90$ and $0.37-0.83$ ) (Table II). In the recessive model, the $1 \mathrm{G} / 1 \mathrm{G}$ genotype at $M M P-1 \mathrm{rs} 1799750$ conferred a decreased risk for CRC compared to combination of $2 \mathrm{G} / 2 \mathrm{G}$ and $1 \mathrm{G} / 2 \mathrm{G}$ genotypes $(2 \mathrm{G} / 2 \mathrm{G}+1 \mathrm{G} / 2 \mathrm{G})(p=0.0186$, adjusted $\mathrm{OR}=0.65,95 \% \mathrm{CI}=0.48-0.94$ ) (Table II). In the dominant model, those who carry $1 \mathrm{G} / 1 \mathrm{G}+1 \mathrm{G} / 2 \mathrm{G}$ at $M M P-1 \mathrm{rs} 1799750$ conferred a decreased susceptibility of CRC compared to the $2 \mathrm{G} / 2 \mathrm{G}$ genotype carriers $(p=0.0061$, adjusted $\mathrm{OR}=0.62$ and $95 \%$ CI=0.42-0.81, Table II). Overall, the $M M P-1$ rs 1799750 genotypes play a critical role in determining personal susceptibility to CRC in Taiwan.
Association analysis of MMP-1 rs1799750 allelic frequencies with $C R C$ risk. The allelic frequency analysis of MMP-1 rs 1799750 with CRC risk was performed and is presented in Table II. Consistent with the major finding in Table II, there is an obvious difference in the distribution of allelic frequencies between the CRC and healthy control groups regarding $M M P-1$ rs1799750 (Table III). In detail, those subjects carrying $1 \mathrm{G}$ allele at $M M P-1$ rs 1799750 were lower in the CRC group (34.9\%) than those in the control group $(43.2 \%)$ (adjusted $\mathrm{OR}=0.73,95 \% \mathrm{CI}=0.52-0.81$, $p=0.0012$ ) (Table III).

Interaction of personal habits with MMP-1 rs1799750 genotype on CRC risk. Since cigarrete smoking and alcohol drinking habits serve as risk factors for CRC in Taiwan, we were interested to examine the interactions between the genotype of $M M P-1$ rs 1799750 with personal cigarette smoking and alcohol drinking status. Firstly, among nonsmokers, those with $M M P-1$ rs $17997501 \mathrm{G} / 2 \mathrm{G}$ and $1 \mathrm{G} / 1 \mathrm{G}$ genotypes were at 0.70 - and 0.48 -fold odds of having CRC (95\% CI $=0.48-1.01$ and $0.29-0.78, p=0.0551$ and 0.0027 , respectively), while there was no synergistic or additive effect observed among the smokers (Table IV). After adjusting for age, gender, alcohol drinking and BMI status, the statistical significance still existed for the homozygous 
Table IV. Odds ratio for matrix metalloproteinase-1 rs1799750 genotype and colorectal cancer after stratification by smoking status.

\begin{tabular}{|c|c|c|c|c|c|c|c|c|c|c|}
\hline \multirow[t]{2}{*}{ Genotype } & \multicolumn{2}{|c|}{ Non-smokers, $\mathrm{n}$} & \multirow{2}{*}{$\begin{array}{c}\text { OR } \\
(95 \% \mathrm{CI})^{\mathrm{a}}\end{array}$} & \multirow{2}{*}{$\begin{array}{c}\mathrm{aOR} \\
(95 \% \mathrm{CI})^{\mathrm{b}}\end{array}$} & \multirow[t]{2}{*}{$p$-Value } & \multicolumn{2}{|c|}{ Smokers, $\mathrm{n}$} & \multirow{2}{*}{$\begin{array}{c}\text { OR } \\
(95 \% \mathrm{CI})^{\mathrm{a}}\end{array}$} & \multirow{2}{*}{$\begin{array}{c}\mathrm{aOR} \\
(95 \% \mathrm{CI})^{\mathrm{b}}\end{array}$} & \multirow[t]{2}{*}{$p$-Value } \\
\hline & Controls & Cases & & & & Controls & Cases & & & \\
\hline $2 \mathrm{G} / 2 \mathrm{G}$ & 94 & 122 & 1.00 (ref) & $1.00(\mathrm{ref})$ & & 30 & 38 & 1.00 (ref) & 1.00 (ref) & \\
\hline $1 \mathrm{G} / 2 \mathrm{G}$ & 124 & 112 & $0.70(0.48-1.01)$ & $0.68(0.45-1.01)$ & 0.0551 & 39 & 39 & $0.79(0.41-1.52)$ & $0.72(0.38-1.47)$ & 0.4776 \\
\hline $1 \mathrm{G} / 1 \mathrm{G}$ & 60 & 37 & $0.48(0.29-0.78)$ & $0.45(0.27-0.75)$ & $0.0027 *$ & 15 & 14 & $0.74(0.31-1.76)$ & $0.71(0.30-1.68)$ & 0.4916 \\
\hline Total & 278 & 271 & & & & 84 & 91 & & & \\
\hline
\end{tabular}

CI, Confidence interval; aOR, adjusted odds ratio. aBy multivariate logistic regression analysis; by multivariate logistic regression analysis after adjusted for confounding factors age, gender, alcohol consumption and BMI status; *Bold values indicate statistical significance.

Table V. Odds ratios for matrix metalloproteinase-1 rs1799750 genotype and colorectal cancer after stratification by alcohol drinking status.

\begin{tabular}{|c|c|c|c|c|c|c|c|c|c|c|}
\hline \multirow[t]{2}{*}{ Genotype } & \multicolumn{2}{|c|}{ Non-drinkers, $\mathrm{n}$} & \multirow{2}{*}{$\begin{array}{c}\text { OR } \\
(95 \% \mathrm{CI})^{\mathrm{a}}\end{array}$} & \multirow{2}{*}{$\begin{array}{c}\mathrm{aOR} \\
(95 \% \mathrm{CI})^{\mathrm{b}}\end{array}$} & \multirow[t]{2}{*}{$p$-Value } & \multicolumn{2}{|c|}{ Drinkers, $\mathrm{n}$} & \multirow{2}{*}{$\begin{array}{c}\text { OR } \\
(95 \% \mathrm{CI})^{\mathrm{a}}\end{array}$} & \multirow{2}{*}{$\begin{array}{c}\mathrm{aOR} \\
(95 \% \mathrm{CI})^{\mathrm{b}}\end{array}$} & \multirow[t]{2}{*}{$p$-Value } \\
\hline & Controls & Cases & & & & Controls & Cases & & & \\
\hline $2 \mathrm{G} / 2 \mathrm{G}$ & 105 & 139 & 1.00 (ref) & 1.00 (ref) & & 19 & 21 & 1.00 (ref) & 1.00 (ref) & \\
\hline $1 \mathrm{G} / 2 \mathrm{G}$ & 143 & 134 & $0.71(0.50-1.00)$ & $0.69(0.46-1.02)$ & 0.0501 & 20 & 17 & $0.77(0.31-1.88)$ & $0.75(0.33-1.90)$ & 0.5655 \\
\hline $1 \mathrm{G} / 1 \mathrm{G}$ & 63 & 45 & $0.54(0.34-0.85)$ & $0.51(0.31-0.81)$ & 0.0080 * & 12 & 6 & $0.45(0.14-1.44)$ & $0.49(0.19-1.53)$ & 0.1758 \\
\hline Total & 311 & 318 & & & & 51 & 44 & & & \\
\hline
\end{tabular}

CI, Confidence interval; aOR, adjusted odds ratio. aBy multivariate logistic regression analysis; by multivariate logistic regression analysis after adjusted for confounding factors age, gender, smoking and BMI status; *Bold values indicate statistical significance.

1G/1G (adjusted OR=0.45, 95\% CI=0.27-0.75) (Table IV). Secondly, among non-alcohol drinkers, people with $M M P-1$ rs $17997501 \mathrm{G} / 2 \mathrm{G}$ and $1 \mathrm{G} / 1 \mathrm{G}$ genotypes were at $0.71-$ and 0.54 -fold odds of having CRC $(95 \% \mathrm{CI}=0.50-1.00$ and 0.34 $0.85, p=0.0501$ and 0.0080 , respectively), while there was no synergistic or additive effect observed among alcohol drinkers (Table V). After adjusting for age, gender, cigarrete smoking and BMI status, the statistical significance still existed for the homozygous $1 \mathrm{G} / 1 \mathrm{G}$ (adjusted $\mathrm{OR}=0.51$, $95 \% \mathrm{CI}=0.31-0.81$, Table V).

Correlation between genotypes of MMP-1 rs1799750 and clinicopathological features. The correlations between genotypes of MMP-1 rs1799750 and clinicopathological features among the $362 \mathrm{CRC}$ patients were analyzed and the results are shown in Table VI. No statistically significant correlation was observed between A MMP-1 rs1799750 genotypic distributions and age, gender, BMI, tumor size or location (all $p>0.05$ ) (Table VI). Interestingly, the percentages of $1 \mathrm{G} / 1 \mathrm{G}$ genotype of $M M P-1$ rs1799750 were statistically lower among the CRC patients with lymph node metastasis $(7.2 \%)$ than those without lymph node involvement (19.0\%, $p=0.0052$ ) (Table VI).

\section{Discussion}

MMPs play a critical role in the metabolism of extracellular matrix components, and any imbalance of the extracellular microenvironment may be related to initiation and progression of cancer. MMP-1 specifically breaks down the interstitial collagens, type I, II, III, VI and X. It is such an essential protein that no knockout murine studies are available so far. Revealing the association of $M M P-1$ genotypes with CRC risk will not only advance our understanding of the mechanisms underlying tumorigenesis, but also facilitate the improvement of novel therapeutics.

The positive association of $M M P-1$ rs 1799750 genotypes with CRC risk (Tables II and III) is consistent with previous reports in childhood leukemia (28), gastric cancer (29) nasopharyngeal carcinoma (30) and pterygium (19). In a meta-analysis investigating more than 38,000 subjects, the results also indicated that the genotypes of $M M P-1$ rs1799750 may be associated with colorectal, head and neck and renal cancer risk (31). However, in other types of cancers, the genotypes of MMP-1 rs1799750 may not directly contribute to susceptibility determination (17, 3235), which indicated that the MMP-1 rs1799750 genotypes 
Table VI. Correlation between matrix metalloproteinase-1 rs1799750 genotypes and clinicopathological properties of 362 colorectal cancer patients.

\begin{tabular}{|c|c|c|c|c|c|}
\hline \multirow[t]{2}{*}{ Characteristics } & \multicolumn{3}{|c|}{ Case number } & \multirow[t]{2}{*}{ Genotypes } & \multirow[t]{2}{*}{$p$-Value ${ }^{\mathrm{a}}$} \\
\hline & $2 \mathrm{G} / 2 \mathrm{G}(\%)$ & 2G/1G (\%) & $1 \mathrm{G} / 1 \mathrm{G}(\%)$ & & \\
\hline \multicolumn{6}{|l|}{ Age (years) } \\
\hline$\leq 60$ & 95 & $36(37.9)$ & $40(42.1)$ & $19(20.0)$ & \\
\hline$>60$ & 267 & $124(46.4)$ & $111(41.6)$ & $32(12.0)$ & 0.1131 \\
\hline \multicolumn{6}{|l|}{ Gender } \\
\hline Male & 203 & 85 (41.9) & $88(43.3)$ & $30(14.8)$ & \\
\hline Female & 159 & $75(47.2)$ & $63(39.6)$ & $21(13.2)$ & 0.6007 \\
\hline \multicolumn{6}{|l|}{ BMI } \\
\hline$<24$ & 193 & $86(44.6)$ & 77 (39.9) & $30(15.5)$ & \\
\hline$\geq 24$ & 169 & $74(43.8)$ & $74(43.8)$ & $21(12.4)$ & 0.6185 \\
\hline \multicolumn{6}{|l|}{ Tumor size } \\
\hline$<5 \mathrm{~cm}$ & 195 & $86(44.1)$ & $78(40.0)$ & 31 (15.9) & \\
\hline$\geq 5 \mathrm{~cm}$ & 167 & $74(44.3)$ & $73(43.7)$ & $20(12.0)$ & 0.5273 \\
\hline \multicolumn{6}{|l|}{ Location } \\
\hline Colon & 257 & $111(43.2)$ & 107 (41.6) & $39(15.2)$ & \\
\hline Rectum & 105 & 49 (46.7) & $44(41.9)$ & $12(11.4)$ & 0.6226 \\
\hline \multicolumn{6}{|c|}{ Lymph node involvement } \\
\hline Negative & 210 & $90(42.9)$ & $80(38.1)$ & $40(19.0)$ & \\
\hline Positive & 152 & $70(46.1)$ & $71(46.7)$ & $11(7.2)$ & $0.0052 *$ \\
\hline
\end{tabular}

aBased on Chi-square test without Yates's correction; *Bold value indicates statistical significance.

may be indirectly involved in carcinogenesis. The detailed mechanisms of how MMP-1 rs1799750 genotypes interact with other molecules leading to CRC need further investigation. One possible explanation is that $M M P-1$ rs1799750 2G/2G genotype may elevate the transcriptional activity of MMP-1, leading to a higher expression of MMP1 in the tissue, which activates the breakdown of collagens (23). The possible mechanism make sense that the $1 \mathrm{G} / 1 \mathrm{G}$ genotype at MMP-1 rs1799750 may be associated with a lower risk of local lymph node metastasis (Table VI).

There were so many environmental or clinical factors involved in CRC risk, such as age, gender, familial CRC history, diet, alcohol consumption, and obesity, tumor site, size, grade, histologic type, TNM stage, and carcinoembryonic antigen (CEA) level, and they all have been reported to affect the overall survival of CRC patients (36-39). But the study is conducted form the viewpoint of epidemiology and lack of genetic data. In the current study, we combined the demographic data, in addition to clinical-pathological records, with genotyping data and reported that $M M P-1 \mathrm{rs} 17997501 \mathrm{G} / 1 \mathrm{G}$ genotypes interacted with non-smoking (Table IV) and non-alcohol drinking habits (Table V) to influence the CRC risk. However, the etiology of how $M M P-1$ rs1799750 1G/1G genotypes interacted with nonsmoking and non-alcohol drinking habits to influence the CRC risk needs further investigation.

In conclusion, we provided evidence for the association of polymorphisms at $M M P-1$ rs1799750 with CRC risk. Our results suggest that the $1 \mathrm{G} / 2 \mathrm{G}$ and $1 \mathrm{G} / 1 \mathrm{G}$ genotypes of the rs1799750 confer personal susceptibility to risk among Taiwanese. These polymorphisms may also serve as predictors for better prognosis, such as lower rate of metastasis.

\section{Conflicts of Interest}

The Authors have declared no conflicts of interest regarding this study.

\section{Authors' Contributions}

Research design: Wu MH, Yueh TC and Chang WS; patient and questionnaire summaries: Wu MH, Yueh TC and Yang MD; experimental work: Chang WS and Tsai CW; statistical analysis: $\mathrm{Fu}$ $\mathrm{CK}$ and $\mathrm{Yu} \mathrm{CC}$; article writing: Tsai $\mathrm{CW}$ and Bau DT; review and revision: Bau DT.

\section{Acknowledgements}

The Authors are grateful to Yu-Chen Hsiau, Yu-Ting Chin and Tai-Lin Huang for their excellent technical assistance. All the participants including those who were not selected into the control group of the study are appreciated. This study was supported mainly by Taichung Armed Forces General Hospital (grant number: TCAFGH-D-109018). The funders had no role in study design, data collection, statistical analysis, or decision to publish or preparation of the manuscript.

\section{References}

1 Siegel RL, Miller KD and Jemal A: Cancer statistics, 2019. CA Cancer J Clin 69(1): 7-34, 2019. PMID: 30620402. DOI: $10.3322 /$ caac 21551 
2 Arnold M, Sierra MS, Laversanne M, Soerjomataram I, Jemal A and Bray F: Global patterns and trends in colorectal cancer incidence and mortality. Gut 66(4): 683-691, 2017. PMID: 26818619. DOI: 10.1136/gutjnl-2015-310912

3 Siegel RL, Torre LA, Soerjomataram I, Hayes RB, Bray F, Weber TK and Jemal A: Global patterns and trends in colorectal cancer incidence in young adults. Gut 68(12): 2179-2185, 2019. PMID: 31488504. DOI: 10.1136/gutjnl-2019-319511

4 Douaiher J, Ravipati A, Grams B, Chowdhury S, Alatise O and Are C: Colorectal cancer-global burden, trends, and geographical variations. J Surg Oncol 115(5): 619-630, 2017. PMID: 28194798. DOI: $10.1002 /$ jso.24578

5 Nagini S: Carcinoma of the stomach: A review of epidemiology, pathogenesis, molecular genetics and chemoprevention. World J Gastrointest Oncol 4(7): 156-69, 2012. PMID: 22844547. DOI: 10.4251/wjgo.v4.i7.156

6 Jayasurya R, Sathyan KM, Lakshminarayanan K, Abraham T, Nalinakumari KR, Abraham EK, Nair MK and Kannan S: Phenotypic alterations in $\mathrm{Rb}$ pathway have more prognostic influence than p53 pathway proteins in oral carcinoma. Mod Pathol 18(8): 1056-1066, 2005. PMID: 15731778. DOI: 10.1038 /modpathol.3800387

7 Butterworth AS, Higgins JP and Pharoah P: Relative and absolute risk of colorectal cancer for individuals with a family history: a meta-analysis. Eur J Cancer 42(2): 216-227, 2006. PMID: 16338133. DOI: 10.1016/j.ejca.2005.09.023

8 Houlston RS and Tomlinson IP: Polymorphisms and colorectal tumor risk. Gastroenterology 121(2): 282-301, 2001. PMID: 11487538. DOI: 10.1053 /gast.2001.26265

9 Wu MH, Tzeng HE, Wu CN, Yueh TC, Peng YC, Tsai CH, Wang YC, Ke TW, Pei JS, Chang WS, Tsai CW and Bau DT: Association of matrix metalloproteinase-9 rs3918242 promoter genotypes with colorectal cancer risk. Anticancer Res 39(12): 6523-6529, 2019. PMID: 31810917. DOI: 10.21873/anticanres. 13867

$10 \mathrm{Wu}$ MH, Hung YW, Gong CL, Chao CC, Yueh TC, Wang SC, Lai YL, Hsu SW, Fu CK, Wang YC, Ke TW, Chang WS, Tsai $\mathrm{CW}$ and Bau DT: Contribution of caspase- 8 genotypes to colorectal cancer risk in taiwan. Anticancer Res 39(6): 27912797, 2019. PMID: 31177115. DOI: 10.21873/anticanres.13406

11 Yueh TC, Hung YW, Shih TC, Wu CN, Wang SC, Lai YL, Hsu SW, Wu MH, Fu CK, Wang YC, Ke TW, Chang WS, Tsai CW and Bau DT: Contribution of murine double minute 2 genotypes to colorectal cancer risk in taiwan. Cancer Genomics Proteomics 15(5): 405-411, 2018. PMID: 30194081. DOI: 10.21873/cgp.20099

12 Yueh TC, Wu CN, Hung YW, Chang WS, Fu CK, Pei JS, Wu MH, Lai YL, Lee YM, Yen ST, Li HT, Tsai CW and Bau DT: The contribution of MMP-7 genotypes to colorectal cancer susceptibility in Taiwan. Cancer Genomics Proteomics 15(3): 207-212, 2018. PMID: 29695403. DOI: 10.21873/cgp.20079

13 Hung YC, Chang WS, Chou AK, Pei JS, Yang MD, Yang HR, Yang TM, Wang YC, Hsiau YC, Chen CP, Chen CC, Yu CC, Tsai CW and Bau DT: Association of adiponectin genotypes with colorectal cancer susceptibility in Taiwan. Anticancer Res 40(3): 1297-1306, 2020. PMID: 32132026. DOI: 10.21873/anticanres.14071

14 de Souza AP, Trevilatto PC, Scarel-Caminaga RM, Brito RB and Line SR: MMP-1 promoter polymorphism: association with chronic periodontitis severity in a Brazilian population. J Clin Periodontol 30(2): 154-158, 2003. PMID: 12622858. DOI: 10.1034/j.1600-051x.2003.300202.x
15 Egeblad $M$ and Werb $\mathrm{Z}$ : New functions for the matrix metalloproteinases in cancer progression. Nat Rev Cancer 2(3): 161-174, 2002. PMID: 11990853. DOI: $10.1038 / \mathrm{nrc} 745$

16 Van Lint $\mathrm{P}$ and Libert C: Chemokine and cytokine processing by matrix metalloproteinases and its effect on leukocyte migration and inflammation. J Leukoc Biol 82(6): 1375-1381, 2007. PMID: 17709402. DOI: 10.1189/jlb.0607338

17 Liao CH, Wu HC, Hu PS, Hsu SW, Shen TC, Hsia TC, Chang WS, Tsai CW and Bau DT: The association of matrix metalloproteinase-1 promoter polymorphisms with prostate cancer in taiwanese patients. Anticancer Res 38(7): 3907-3911, 2018. PMID: 29970511. DOI: 10.21873/anticanres.12675

18 Shen TC, Chang WS, Tsai CW, Chao CY, Lin YT, Hsiao CL, Hsu CL, Chen WC, Hsia TC and Bau DT: The contribution of matrix metalloproteinase-1 promoter genotypes in Taiwan lung cancer risk. Anticancer Res 38(1): 253-257, 2018. PMID: 29277780. DOI: 10.21873/anticanres.12215

19 Tsai CB, Hsia NY, Wang YC, Wang ZH, Chin YT, Huang TL, Yu CC, Chang WS, Tsai CW, Yin MC and Bau DT: The significant association of $M M P-1$ genotypes with Taiwan pterygium. Anticancer Res 40(2): 703-707, 2020. PMID: 32014911. DOI: 10.21873 /anticanres. 14000

20 Chen GL, Shen TC, Chang WS, Tsai CW, Li HT, Chuang CL, Lai YL, Yueh TC, Hsia TC, Wang SC and Bau DT: The contribution of $M M P-7$ promoter polymorphisms to Taiwan lung cancer susceptibility. Anticancer Res 38(10): 5671-5677, 2018. PMID: 30275186. DOI: 10.21873/anticanres.12903

21 Pendás AM, Santamaría I, Alvarez MV, Pritchard M and LópezOtín C: Fine physical mapping of the human matrix metalloproteinase genes clustered on chromosome 11q22.3. Genomics 37(2): 266-268, 1996. PMID: 8921407. DOI: 10.1006/geno.1996.0557

22 Goldberg GI, Wilhelm SM, Kronberger A, Bauer EA, Grant GA and Eisen AZ: Human fibroblast collagenase. Complete primary structure and homology to an oncogene transformation-induced rat protein. J Biol Chem 261(14): 6600-6605, 1986. PMID: 3009463

23 Tower GB, Coon CI and Brinckerhoff CE: The 2G single nucleotide polymorphism (SNP) in the MMP-1 promoter contributes to high levels of MMP-1 transcription in MCF-7/ADR breast cancer cells. Breast Cancer Res Treat 82(2): 75-82, 2003. PMID: 14692651. DOI: 10.1023/B:BREA.0000003948.14026.7c

24 Liu D, Guo H, Li Y, Xu X, Yang K and Bai Y: Association between polymorphisms in the promoter regions of matrix metalloproteinases (MMPs) and risk of cancer metastasis: a meta-analysis. PLoS One 7(2): e31251, 2012. PMID: 22348060. DOI: 10.1371/journal.pone.0031251

25 Huang Z, Yang Q and Huang Z: Identification of critical genes and five prognostic biomarkers associated with colorectal cancer. Med Sci Monit 24: 4625-4633, 2018. PMID: 29973580. DOI: 10.12659/MSM.907224

26 Hozhabri H, Lashkari A, Razavi SM and Mohammadian A: Integration of gene expression data identifies key genes and pathways in colorectal cancer. Med Oncol 38(1): 7, 2021. PMID: 33411100. DOI: 10.1007/s12032-020-01448-9

27 Chen L, Lu D, Sun K, Xu Y, Hu P, Li X and Xu F: Identification of biomarkers associated with diagnosis and prognosis of colorectal cancer patients based on integrated bioinformatics analysis. Gene 692: 119-125, 2019. PMID: 30654001. DOI: $10.1016 /$ j.gene. 2019.01 .001 
28 Pei JS, Hsu PC, Chou AK, Tsai CW, Chang WS, Hsiao CL, Hsu YN, Cheng SP and Bau DT: Matrix metalloproteinase-1 genotype contributes to the risk of non-solid tumor in childhood leukemia. Anticancer Res 36(10): 5127-5132, 2016. PMID: 27798872. DOI: 10.21873 /anticanres.11082

29 Devulapalli K, Bhayal AC, Porike SK, Macherla R, Akka J, Nallari P and Ananthapur V: Role of interstitial collagenase gene promoter polymorphism in the etiology of gastric cancer. Saudi J Gastroenterol 20(5): 309-314, 2014. PMID: 25253367. DOI: 10.4103/1319-3767.141693

30 Tsai CW, Chang WS, Gong CL, Shih LC, Chen LY, Lin EY, Li $\mathrm{HT}$, Yen ST, Wu CN and Bau DT: Contribution of matrix metallopeptidase-1 genotypes, smoking, alcohol drinking and areca chewing to nasopharyngeal carcinoma susceptibility. Anticancer Res 36(7): 3335-40, 2016. PMID: 27354591

31 Peng B, Cao L, Wang W, Xian L, Jiang D, Zhao J, Zhang Z, Wang $X$ and Yu L: Polymorphisms in the promoter regions of matrix metalloproteinases 1 and 3 and cancer risk: a metaanalysis of 50 case-control studies. Mutagenesis 25(1): 41-48, 2010. PMID: 19843588. DOI: 10.1093/mutage/gep041

32 Zhou $\mathrm{H}$ and Zhu X: Association between matrix-metalloproteinase polymorphisms and prostate cancer risk: a meta-analysis and systematic review. Cancer Manag Res 10: 5247-5259, 2018. PMID: 30464622. DOI: 10.2147/CMAR.S177551

$33 \mathrm{Zhu} \mathrm{XM}$ and Sun WF: Association between matrix metalloproteinases polymorphisms and ovarian cancer risk: A meta-analysis and systematic review. PLoS One 12(9): e0185456, 2017. PMID: 28957437. DOI: 10.1371/journal.pone.0185456

34 Wang L and Kong B: Analysis of the association of matrix metalloproteinase-1 gene promoter (rs 1799750) polymorphism and risk of ovarian cancer. Int J Gynecol Cancer 25(6): 961-967, 2015. PMID: 25950130. DOI: 10.1097/IGC.0000000000000463
35 Hsiao CL, Liu LC, Shih TC, Lai YL, Hsu SW, Wang HC, Pan SY, Shen TC, Tsai CW, Chang WS, Su CH, Way TD, Chung JG and Bau DT: The association of Matrix Metalloproteinase-1 promoter polymorphisms with breast cancer. In Vivo 32(3): 487491, 2018. PMID: 29695550. DOI: 10.21873/invivo.11265

36 Chen PC, Lee JC and Wang JD: Estimation of life-year loss and lifetime costs for different stages of colon adenocarcinoma in taiwan. PLoS One 10(7): e0133755, 2015. PMID: 26207912. DOI: 10.1371/journal.pone.0133755

37 Beckmann KR, Bennett A, Young GP, Cole SR, Joshi R, Adams J, Singhal N, Karapetis C, Wattchow D and Roder D: Sociodemographic disparities in survival from colorectal cancer in South Australia: a population-wide data linkage study. BMC Health Serv Res 16: 24, 2016. PMID: 26792195. DOI: 10.1186/s12913-016-1263-3

38 Perron L, Daigle JM, Vandal N, Guertin MH and Brisson J: Characteristics affecting survival after locally advanced colorectal cancer in Quebec. Curr Oncol 22(6): e485-492, 2015. PMID: 26715887. DOI: 10.3747/co.22.2692

39 Wang R, Wang MJ and Ping J: Clinicopathological features and survival outcomes of colorectal cancer in young versus elderly: A population-based cohort study of SEER 9 registries data (1988-2011). Medicine (Baltimore) 94(35): e1402, 2015. PMID: 26334895. DOI: 10.1097/MD.0000000000001402

Received January 19, 2021

Revised February 4, 2021

Accepted February 15, 2021 